\title{
PURCHASE INTENTION ON LOW-COST SMARTPHONE IN TERMS OF WELL-ESTABLISHED SMARTPHONE BRAND USERS
}

\section{Radha Shafira Putri, Theresia Christania Suarly, William Alaric, Peri Akbar Manaf}

Business Management Program, Management Department, BINUS Business School Master Program, Bina Nusantara University, Jakarta, Indonesia

\author{
Article Information \\ Received: 23 July 2021 \\ Accepted: 26 August 2021 \\ Published: 30 September 2021 \\ DOI: $10.33555 / \mathrm{embm} . v 8 \mathrm{i} 2.187$ \\ Corresponding Author: \\ Radha Shafira Putri \\ Jakarta, Indonesia \\ Email: radha.putri@binus.ac.id \\ ISSN $2338-8854$ \\ eISSN 2620-9918
}

\begin{abstract}
This study investigates the effects of brand image on customer trust and perceived value and its influence on the purchase intention of Realme smartphones in Indonesia. The model for this study indicates the effects of brand image on customer trust and customer perceived value, and the effects of customer trust and customer perceived value to the purchase intention. The data sample was collected from 265 respondents using non-probability sampling techniques with the purposive sampling method through online surveys. The use of the PLS-SEM methodology by SmartPLS is intended to test the predictive relationship between constructs by seeing whether there is a relationship or influence between constructs. The results of using PLS-SEM show the significance of customer trust and customer perceived value on affecting purchase intention, whereby brand image has a significant and positive impact on customer trust and customer perceived value in Realme smartphones, from the high-cost smartphone brand users' perspectives. Based on prior research, we apply a theory from a new angle by examining brand image influence on consumer trust and customer perceived value and its impact on purchase intention in Realme smartphones as observed by users of well-known smartphone brands.

Keywords: Brand Image, Customer Perceived Value, Customer Trust, Purchase Intention, Smartphone
\end{abstract}




\section{Introduction}

In recent decades, smartphone has become an essential tool widely used by many people worldwide (Martins et al., 2019). It is proven with the data that stated the numbers of smartphone users globally had increased significantly by $74 \%$, from 3.6 billion in 2016 to 6 billion in 2021 (Statista, 2021c). When buying a smartphone, customers usually consider many aspects, such as smartphone quality and technical features, since they will use it to support their activities (Martins et al., 2019). The smartphone industry is one of many industries with tough competition between many companies that do business in this industry. Smartphone Industry in Indonesia is no exception, due to the rise of internet network infrastructure in all corners of Indonesia and smartphone price is getting cheaper and better. As Indonesia's population keeps growing, Indonesia's smartphone market is getting bigger since more people will need a smartphone as a multi-function tool in their lives. The enormous market of Indonesian smartphone users is reflected by the growth around $111 \%$ from below 100 million users in 2016 to around an estimated 210 million users in 2021 (Statista, 2021a). Indonesia has also become the fourth-largest smartphone user globally (Statista, 2021d) and nowadays has the biggest smartphone market in Southeast Asia. This phenomenon impacting many companies trying to compete for their share in the Indonesian smartphone market.

When purchasing a smartphone, customers in Indonesia are looking for features that smartphone offer, while brand image also helps influence customers' decisions (Macmud \& Hidayat, 2020). Another research found that customers tend to prefer the smartphone brand they trust for smartphone selection and are even willing to spend more money from the smartphone brand they trust (Kim \& Lee, 2018). In recent years, many flagships smartphones cost over a thousand dollars. Although they offer better qualities and features, the demand for flagship smartphones is declining. This is because people care about the price level of the smartphone and what they will get for that price (The Economist, 2014). In the present market, the smartphone industry worldwide is dominated by two dominant companies: Samsung and Apple (Statista, 2021b). In this market where the demand for affordable smartphones is rising, many new smartphone companies offer many more affordable smartphones with the same quality to gain more market share. One of those smartphone companies is Realme, established on $28^{\text {th }}$ August 2018 and competing in 27 countries (Realme, 2020). In the Indonesian market in November 2020 , Samsung is still dominated by a $26 \%$ market share, while the low-cost smartphone brand, Realme, owns 6\% of Indonesia's smartphone market (Statista, 2020).

Previous studies on the smartphone have investigated the brand's effect on smartphone customer purchase, with many concentrating on brand's image direct effect on purchase intention without exploring other possible variables between a company's brand image and customer purchase intention (Alrwashdeh et al., 2019). For instance, brand image can impact the consumer perceived value variable (Dhanabalan et al., 2018), an important variable that plays a role in the smartphone industry. Customer trust in Lien et (2015) study also found to be a critical variable since smartphone purchase is high-involvement demanding for the customers. Later, the customer perceived value variable and customer trust variable will influence the purchase intention (Ali et al., 2018; Peng et al., 2019).

Realme is a relatively new smartphone brand that offers a low-cost brand image. Therefore, this study investigates the influence of the brand image in Realme as a low-cost smartphone brand from the perspective of high-cost smartphone brand 
users. This study aims to explain the likelihood of high-cost smartphone brand users purchasing a smartphone from the low-cost smartphone brand and to know the role of brand image for Realme to compete for the smartphone market share in Indonesia. This study wants to get a deeper insight into how the high-cost smartphone brand users see the low-cost smartphone brand and how willing they are to purchase smartphones from the low-cost smartphone brand. Simultaneously, it gives a deeper understanding of the effects brand image has on purchase intention variables, with consumer trust and perceived value acting as variables between them.

\section{Literature Review}

Companies dedicated to enhancing brand image enable them to improve the buying behavior of their customers. The brand image itself has a positive effect on consumer buying behavior because it can influence the decision-making of customers involved in the exchange and simultaneously increase the likelihood of purchase intention at the time of the transaction (Chen et al., 2020). Also, perceived value is a subjective concept because it depends on various contexts that determine the distinctive nature of different products and has been recognized as a major determinant of consumer buying behavior (Woo \& Kim, 2019). Thus, value can be an important component related to today's business market because it is based on the evaluation of the consumer received and paid for the purchase of the product/service. The internal state of individual consumers is driven by values such as open moral self-identity. The results show that the purchase behavior results from the conversion of the purchase intention as a behavioral response (Talwar et al., 2021). Purchases advertised due to intentions driven by internal consumer factors, such as openness and moral selfidentification. The customer's trust and openness towards the brand or smartphone will affect the customer's intention to buy a smartphone as a behavioral response. Brands must show in-depth knowledge of the various attributes of smartphones to make a good impression (Xu et al., 2016).

\subsection{Brand Image}

Brand image can be described as what customers feel spontaneous when they hear or see a brand (Gardner \& Levy, 1955). Therefore, companies need to create a good brand image to influences the customer purchase intention. Trust is substantially influenced by brand image and a smartphone with a good image influences the customer on how they will think about it and why they need to purchase it. A study done by Lee \& Lee (2018) stated that an excellent and positive brand image would be beneficial for companies.

\subsection{Customer Trust}

Trust is defined as the reliability of each associated party in a particular exchange relationship (Rotter, 1967). Customer trust is considered how willing the customer is to do purchase activity for a company (Ye et al., 2019). Customer trust in a company comes from a long process until both sides trust each other, and it will make the customer more retain to a company that they trust (Rita et al., 2019). Based on the studies above, customer trust is defined as how customers want to stick with company products and services. Thus, customer trust towards a company is not only because of their excellent image or branding but also how its product and services impact environmental sustainability as an example of good corporate.

\subsection{Customer Perceived Value}

Consumer perceived value refers to the trade-off of what consumers received and compromises to obtain and use the product (Zeithaml, 1988). In the context of smartphones, it can be related to the benefits that consumers get and is shown when it causes consumer satisfaction by using certain smartphones. Bringing more benefits to the customer will help increase 
customer engagement that enhances the customer's perceived value, which will improve the customer's relationship and beneficial for the company (Loureiro et al., 2019). Therefore, customer perceived value is defined as the customer's overall evaluation of the usefulness of a product or service based on their perception of what is obtained and provided and influences the customer's intention to buy a smartphone.

\subsection{Purchase Intention}

Purchase intention is described as consumers' willingness to buy a specific product, and travel companies can deliver risk-relieving information to increase customer purchase intention and benefit them (Mohseni et al., 2018). Purchase intention is how the customers are willing to make an effort to perform a behavior or complete a purchase (Ajzen, 1991). Purchase intention also shows the extent of customers' planning or willingness to acquire specific product in the near future, which is influenced by a relatable advertisement of the smartphone brand, engaging smartphone brand web design quality, and attractive brand awareness campaign of the smartphone (Martins et al., 2019). Thus, concluding from previous studies, purchase intention can be concluded as the customers' willingness to purchase a product or service.

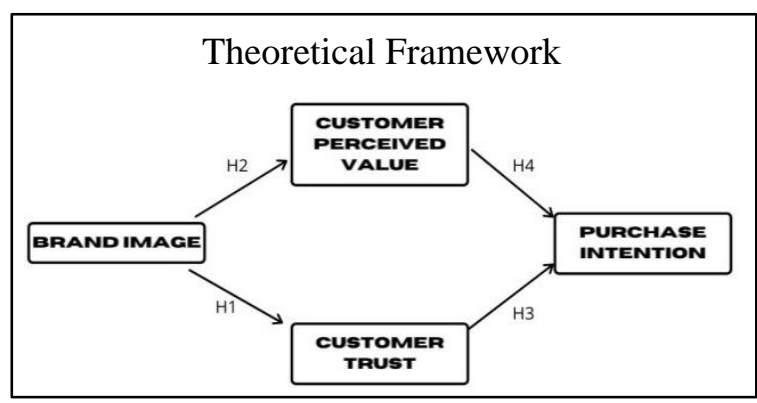

Figure 1. The Research Model

\subsection{Brand Image on Customer Trust}

Several studies found that a brand image consists of shop image, product image, brand's quality, and other indicators that affected trust. Thus, ideals brand image could influence trust in the brand. Based on the empirical data on their research, (Yeh \& $\mathrm{Li}, 2009)$ stated that vendors in mobile commerce with good brand Image and give a customer exceptional satisfaction directly affect customer trust. another data from Lien (2015) illustrates that brand image is an antecedent in determining trust. Customers trust a smartphone with a leading role in this industry. Thus, a good brand image could increase the customer trust in the product or services of the brand. Based on the prior studies, brand image is substantially impactful on customer's trust. Hence, the proposed hypothesis is:

$\mathrm{H}_{1}$ : Brand Image positively influence Customer Trust

\subsection{Brand Image on Customer Perceived Value}

A company's perceived value could be increased by developing a powerful and positive brand image. According to research, brand image is positively associated with consumer perceived value; this research also interprets brand image by the price that brands offered, product or merchandise, the customer service of the brand, and the store's architecture that brand has (Graciola et al., 2020). A study about fast-casual restaurant image shows that restaurant image has a strong connection to the perceived value. (Ryu et al., 2008). With a differentiated image and different personality compared to other smartphones, customers considered a smartphone image that brings a high value. Therefore, we need to investigate more about the influence in the context of a smartphone. The suggested hypothesis is stated as follows:

\section{$\mathrm{H}_{2}$ : Brand Image positively influence Customer Perceived Value}

\subsection{Customer Trust on Purchase Intention}

Trust is an essential variable that influences purchase intention. Customers are willing to waste their time and money to buy the brand's products that they trust. According to Chen \& Chang (2012), the results show that when customers already trust a 
particular brand and know that the brand is honest, it will affect the purchase intention. (Ali et al., 2018) also stated that trust significantly influences purchase intention. By implant the notions of trust could improve customer purchase intention. The customer is willing to buy the smartphone when the customer trusts and is satisfied by the smartphone's operation standards. The above studies show that there is an impact of customer trust toward purchase intention. Thus, we are proposing the following hypothesis:

H3: Customer Trust positively influence Purchase Intention

\subsection{Customer Perceived Value on Purchase Intention}

Previous research also mentioned the importance of perceived value towards customers' intent to purchase due to its portrayal of a good product value, causing customers to perceive a good purchase and be satisfied (Konuk, 2018). Customers will also seriously consider purchasing a smartphone if the smartphone provides a great value compared to other smartphones. Later, the price will have a beneficial impact on perceived value and a strong effect on purchase intention (Weisstein et al., 2017). However, the customer perceived value influence toward purchase intention in the context of smartphones has to be researched. Therefore, the proposed hypothesis is:

$\mathrm{H}_{4}$ : Customer Perceived Value positively influence Purchase Intention

\section{Methodology}

This research is a quantitative type with a non-probability sampling methodology. This research applied a purposive sample drawn of multiple kinds of non-probability sampling in determining the target respondents. The target respondents are Apple and Samsung smartphone users who have replaced their smartphone at least once and have used it for at least three years and consider brand factors and long-term use of buying a smartphone. This sampling is carried out limited to certain types of people who can provide the desired information because they are the only ones who have the criteria set by the researcher or they fit some predetermined criteria (Sekaran \& Bougie, 2014). In collecting the data, an online questionnaire was used for this study because online questionnaires are used to gain a deeper understanding of consumer opinions and preferences created with databases as web forms to store answers and statistical software to provide the statistical analysis (Sekaran \& Bougie, 2014). This study obtained 265 respondents who live in Indonesia and meet the criteria through an online questionnaire. The reason behind gathering a sample from Apple and Samsung users is to gain a new perspective on whether the Apple and Samsung users ever think or intend to purchase a Realme smartphone based on the factors included in this research. To determine the sample size, the generally accepted ratio for minimizing problems with deviations from normality is ten respondents for each parameter evaluated in the model (Hair et al., 2018). Questionnaires were made with 23 item questions. Respondents were asked six questions about brand image, five customer trust questions, six questions about perceived values, and six questions about purchase intention.

\subsection{Measurement}

This research topic consists of four variables. There is brand image, customer perceived value, customer trust, and purchase intention. A questionnaire in previous literature studies using the 5-Point Likert Scale ranging from "Strongly disagree" to "Strongly agree" for all questions was utilized to ensure each variable's validity. For brand image measurements, there are six items from (Lee \& Lee, 2018; Lin et al., 2020; Sasmita $\&$ Mohd Suki, 2015), and there are five items to measures customer trust (Cheshin et al., 2018; Paparoidamis et al., 2019; Rita et al., 2019; Ye et al., 2019). There are also six items to measure customer perceived 
value adapted from (Konuk, 2018, 2019; Loureiro et al., 2019; Ryu et al., 2012; Weisstein et al., 2017) and six items for purchase intention were adapted from (Buil et al., 2013; Jeng \& Lo, 2019; Konuk, 2018; Peng et al., 2019).

Table 1. Variable and Indicators

\begin{tabular}{|c|c|c|c|}
\hline Construct & Item & & Source \\
\hline \multirow[t]{6}{*}{$\begin{array}{l}\text { Brand Image } \\
\text { (BI) }\end{array}$} & $\mathrm{BI}_{1}$ & $\begin{array}{l}\text { This smartphone brand has a differentiated image in } \\
\text { comparison with the other product/brand }\end{array}$ & (Sasmita \& Suki, 2015) \\
\hline & $\mathrm{BI}_{2}$ & $\begin{array}{l}\text { The smartphone brand has a personality that } \\
\text { distinguishes it from competitors }\end{array}$ & (Lin et al., 2020) \\
\hline & $\mathrm{BI}_{3}$ & $\begin{array}{l}\text { It is a smartphone brand that does not disappoint its } \\
\text { customers }\end{array}$ & \\
\hline & $\mathrm{BI}_{4}$ & It is one of the best brands in the smartphone sector & \\
\hline & $\mathrm{BI}_{5}$ & $\begin{array}{l}\text { This smartphone brand play a leading role in the } \\
\text { industry }\end{array}$ & (Lee \& Lee, 2018) \\
\hline & $\mathrm{BI}_{6}$ & $\begin{array}{l}\text { This smartphone brands' image is differentiated from } \\
\text { other brands }\end{array}$ & \\
\hline \multirow{5}{*}{$\begin{array}{l}\text { Customer } \\
\text { Trust (CT) }\end{array}$} & $\mathrm{CT}_{1}$ & $\begin{array}{l}\text { I believe this smartphone brand revealed all of the } \\
\text { relevant information to me }\end{array}$ & (Cheshin et al., 2018) \\
\hline & $\mathrm{CT}_{2}$ & I trust this smartphone brand & (Ye et al., 2019) \\
\hline & $\mathrm{CT}_{3}$ & I believe what this smartphone company tells me & \\
\hline & $\mathrm{CT}_{4}$ & This smartphone company is honest & $\begin{array}{l}\text { (Paparoidamis et al., } \\
\text { 2019) }\end{array}$ \\
\hline & $\mathrm{CT}_{5}$ & $\begin{array}{l}\text { I am happy with the standards by which this } \\
\text { smartphone company is operating }\end{array}$ & (Rita et al., 2019) \\
\hline \multirow{6}{*}{$\begin{array}{l}\text { Customer } \\
\text { Perceived } \\
\text { Value (CPV) }\end{array}$} & $\mathrm{CPV}$ & $\begin{array}{l}\text { The smartphone of this brand provides me great value } \\
\text { as compared to others }\end{array}$ & (Ryu et al., 2012) \\
\hline & $\mathrm{CPV}$ & $\begin{array}{l}\text { The overall value of using smartphones of this brand } \\
\text { was high }\end{array}$ & (Konuk, 2019) \\
\hline & $\mathrm{CPV}$ & $\begin{array}{l}\text { I feel that I am getting a good deal when buying a } \\
\text { smartphone at this smartphone company }\end{array}$ & (Loureiro et al., 2019) \\
\hline & $\mathrm{CPV}_{4}$ & The smartphone of this brand is a good buy & (Konuk, 2018) \\
\hline & $\mathrm{CPV}$ & $\begin{array}{l}\text { If I bought a smartphone of this brand, I feel I would be } \\
\text { getting my money worth }\end{array}$ & (Weisstein et al., 2017) \\
\hline & $\mathrm{CPV}_{\mathrm{e}}$ & Buying a smartphone of this brand makes me feel good & \\
\hline \multirow{6}{*}{$\begin{array}{l}\text { Purchase } \\
\text { Intention (PI) }\end{array}$} & $\mathrm{PI}_{1}$ & $\begin{array}{l}\text { My willingness to buy a smartphone of this brand is } \\
\text { high }\end{array}$ & (Peng et al., 2019) \\
\hline & $\mathrm{PI}_{2}$ & $\begin{array}{l}\text { If I were to buy the smartphone, I would consider } \\
\text { buying a smartphone of this brand }\end{array}$ & \\
\hline & $\mathrm{PI}_{3}$ & I plan to purchase a smartphone of this brand & (Konuk, 2018) \\
\hline & $\mathrm{PI}_{4}$ & $\begin{array}{l}\text { I am willing to buy a smartphone of this brand in the } \\
\text { future }\end{array}$ & \\
\hline & $\mathrm{PI}_{5}$ & I will likely purchase a smartphone on this brand & (Jeng \& Lo, 2019) \\
\hline & $\mathrm{PI}_{6}$ & $\begin{array}{l}\text { I would seriously consider buying a smartphone of this } \\
\text { brand }\end{array}$ & (Buil et al., 2013) \\
\hline
\end{tabular}




\section{Results}

\subsection{Profile of Respondents}

The respondents are classified into respondents' origin city, smartphone use, gender, and age in this research. There are 265 respondents in this research, and most of the respondents, 192, originated in the island of Java, where the most dominant city is DKI Jakarta, with 104 respondents. The smartphone that the respondents use is slightly dominated by Samsung, with 134 respondents claimed to use Samsung while 131 respondents use Apple. In the gender context, there are 146 female respondents and 119 male respondents. For the age classification, 220 respondents from between 18 to 24 years old, while 33 respondents from between 25-32 years old, and 12 respondents are at the age of 33-40 years old.

In this research article, we are using PLSSEM was used to get the explanation of the influences between the variables in hypo- theses (Hair et al., 2018), and the tool that we used was SmartPLS 3.0 for analyzing the data since SmartPLS is one of the most popular tools in the form of software application that can be used for PLS-SEM (Wong, 2013). The first measurement model is convergent validity which has two criteria. First, factor loadings should be greater than 0.7 to be categorized as valid (Hair et al., 2018). The second is that all indicators in this research should have at least 0.5 average variances extracted or AVE to be considered valid (Hair et al., 2018).

For the discriminant validity, all the square roots of the average variance extracted should be higher than the correlation with other latent constructs (Fornell \& Larcker, 1981). For the reliability, the composite reliability should be greater than 0.7 (Nunnally, 1994), and Cronbach alpha must also exceed 0.7 (Hair et al., 2018) to know that the constructs are reliable.

Table 2. Respondents' characteristic

\begin{tabular}{llll}
\hline Variable & Category & Frequency & Percentage (\%) \\
\hline Origin & Java & 192 & $72.4 \%$ \\
& Sumatra & 63 & $23.7 \%$ \\
& Sulawesi & 4 & $1.5 \%$ \\
& Kalimantan & 3 & $1.1 \%$ \\
& Nusa Tenggara & 2 & $0.7 \%$ \\
& Papua & 1 & $0.3 \%$ \\
Smartphone & Samsung & 134 & $50.5 \%$ \\
& Apple & 131 & $49.4 \%$ \\
Gender & Female & 146 & $55 \%$ \\
& Male & 119 & $44.9 \%$ \\
Age (Years) & 18 to 24 & 220 & $83 \%$ \\
& 25 to 32 & 33 & $12.4 \%$ \\
& 33 to 40 & 12 & $4.5 \%$ \\
\hline
\end{tabular}




\subsection{Measurement Results}

Table 3 indicates the data about the factor loadings for every indicator. All indicators exceed the minimal factor loading of 0.7 , as seen by factor loadings being above 0.7 on each hand for the average variance extracted (AVE); all constructs have AVE more than the cut-off value of 0.5. Therefore, all variables and indicators are proven to have good convergent validity since all the criteria are met. The right side of Table 3 shows discriminant validity, whereby all square root constructs are the greater square root of average variance extracted to the relation with other latent constructs. According to Fornell \& Larcker (1981), all latent constructs should have a greater AVE square root than the correlation with the other latent constructs. Since all latent constructs have a greater number of AVE square root than the correlation with the other latent constructs, all constructs are considered to have good discriminant validity.

The reliability model has two criterias: the composite reliability being more than 0.7 , and the Cronbach alpha should also be more than 0.7. In Table 2, all latent constructs have composite reliability of more than 0.7 , therefore, all latent constructs meet the composite reliability requirement. All latent constructs also show a higher number than 0.7 in Cronbach alpha, which shows that the survey instrument can consistently determine all constructs. Therefore, all measures that meet discriminant validity and reliability assessments have results indicating that the construct can be used to assess the conceptual model.

Table 3. Constructs with Factor Loadings, Average Variance Extracted, Composite Reliability, Cronbach Alpha, and Discriminant Validity.

\begin{tabular}{ccccccccc}
\hline \multirow{2}{*}{ Constructs } & $\begin{array}{c}\text { Factor } \\
\text { Loadings }\end{array}$ & AVE & CR & CA & \multicolumn{3}{c}{ Correlations Between Constructs } \\
\hline Brand Image & & 0.604 & 0.901 & 0.868 & $\mathbf{0 . 7 7 7}$ & & \\
$\mathrm{BI}_{1}$ & 0.725 & & & & & & \\
$\mathrm{BI}_{2}$ & 0.791 & & & & & & \\
$\mathrm{BI}_{3}$ & 0.76 & & & & & & \\
$\mathrm{BI}_{4}$ & 0.81 & & & & & & \\
$\mathrm{BI}_{5}$ & 0.767 & & & & & & \\
$\mathrm{BI}_{6}$ & 0.806 & & & & & & \\
\end{tabular}

\begin{tabular}{ccccccc}
\hline $\begin{array}{c}\text { Customer } \\
\text { Perceived Value }\end{array}$ & & 0.649 & 0.917 & 0.891 & 0.608 & $\mathbf{0 . 8 0 5}$ \\
$\mathrm{CPV}_{1}$ & 0.811 & & & & & \\
$\mathrm{CPV}_{2}$ & 0.77 & & & & & \\
$\mathrm{CPV}_{3}$ & 0.847 & & & & \\
$\mathrm{CPV}_{4}$ & 0.856 & & & & \\
$\mathrm{CPV}_{5}$ & 0.741 & & & & \\
$\mathrm{CPV}_{6}$ & 0.8 & & & & \\
& & & & & \\
& & & & & \\
\end{tabular}




\begin{tabular}{ccccccccc}
\hline Customer Trust & & 0.618 & 0.89 & 0.846 & 0.641 & 0.693 & $\mathbf{0 . 7 8 6}$ & \\
$\mathrm{CT}_{1}$ & 0.773 & & & & & & & \\
$\mathrm{CT}_{2}$ & 0.782 & & & & & & & \\
$\mathrm{CT}_{3}$ & 0.78 & & & & & & & \\
$\mathrm{CT}_{4}$ & 0.79 & & & & & & & \\
$\mathrm{CT}_{5}$ & 0.804 & & & & & & & \\
& & & & & & & & \\
\hline Purchase & & 0.744 & 0.946 & 0.931 & 0.596 & 0.687 & 0.641 & $\mathbf{0 . 8 6 2}$ \\
Intention & & & & & & & & \\
$\mathrm{PI}_{1}$ & 0.85 & & & & & & & \\
$\mathrm{PI}_{2}$ & 0.867 & & & & & & & \\
$\mathrm{PI}_{3}$ & 0.863 & & & & & & & \\
$\mathrm{PI}_{4}$ & 0.89 & & & & & & & \\
$\mathrm{PI}_{5}$ & 0.895 & & & & & & & \\
$\mathrm{PI}_{6}$ & 0.806 & & & & & & & \\
\hline
\end{tabular}

\subsection{Hypotheses Results}

As shown in Table 4, hypothesis 1 shows original sample of 0.641 , T-statistics of 16.285, and P-values of 0.0000. This demonstrates that brand image positively and significantly affects customer trust, implying the first hypothesis of a positive effect of brand image on consumer trust is validated and supports Lien (2015). Hypothesis 2 shows original sample of 0.608 , T-statistics of 12.975, and P-values of 0.000 . This proves that brand image positively and significantly influences customer perceived value, supporting the second hypothesis and research results from Dhanabalan (2018). Next is hypothesis 3, which has an original sample of 0.317 , Tstatistics of 4.887, and P-values of 0.000 .
Therefore, customer trust has significant and positive on purchase intention. Thus, it supports hypothesis 3, which stated a positive influence from customer trust towards purchase intention and supports Ali's (2018) research result. The last is hypothesis 4 that has an original sample of 0.467 , T-statistics of 7.733, and P-values of 0.000 . Hence, hypothesis 4 describes a positive and significant influence from customer perceived value towards the purchase intention and supports hypothesis 4 of a positive effect on purchase intention from customer perceived value. Concurrently, it also supports the research result from Weisstein (2017). With the results above, it is proven that all hypotheses are supported. 
Table 4. Hypotheses Results

\begin{tabular}{llllll}
\hline Hypotheses & Path & Original Sample $(\beta)$ & T-Statistics & P-values & Results \\
\hline $\mathrm{H}_{1}$ & BI -> CT & 0.641 & 16.285 & 0.0000 & Supported \\
$\mathrm{H}_{2}$ & BI -> CPV & 0.608 & 12.975 & 0.0000 & Supported \\
$\mathrm{H}_{3}$ & CT -> PI & 0.317 & 4.887 & 0.0000 & Supported \\
$\mathrm{H}_{4}$ & CPV -> PI & 0.467 & 7.733 & 0.0000 & Supported \\
\hline
\end{tabular}

\section{Discussion}

This study proves that brand image influences customer perceived value and trust and later both variables influence the purchase intention, towards customers' perception of high-cost smartphone brands and Realme as a low-cost smartphone brand in Indonesia.

Table 5. R Square

\begin{tabular}{ll}
\hline & R Square \\
\hline Customer Trust & 0.410 \\
Customer Perceived Value & 0.369 \\
Purchase Intention & 0.524 \\
\hline
\end{tabular}

With a result of $\beta$ being 0.641 and a Tstatistic of 16.285 , the first hypothesis demonstrates a strong and positive effect of brand image on consumer trust. Thus, Lien (2015) stated that brand image is considered a major influence on consumer trust. Table 6 shows that brand image can explain $41 \%$ of customer trust while other variables influence the rest. The second hypothesis also indicates a significant and positive influence from brand image to customer perceived value which is proved by the result of $\beta$ of 0.608 and T-statistics of 12.975. The second hypothesis is consistent with Dhanabalan's (2018) result, and this research shows that brand image can explain $36.9 \%$ of customer perceived value while other factors influence the rest. To establish a positive brand image, having a distinctive brand image from other businesses is helpful. Also, strive not to disappoint them. These variables are likely to have a moderate influence on consumers' trust and perceived value.

The third hypothesis shows a positively significant influence of customer trust to purchase intention with the result $\beta$ of 0.317 and T-statistics of 4.887, making this study consistent with the past research done by Ali (2018). The final hypothesis demonstrates how positively and significantly effective customer perceived value is toward purchase intention, as shown by to $\beta$ of 0.467 and T-statistics of 7.733. This is consistent with the research result from Weisstein (2017). Customer trust and perceived value can explain 52.4\% of purchase intention while other variables influence the rest.

\subsection{Managerial Implications}

In the perspective of high-cost smartphone brands to purchase low-cost smartphone brands, this research could provide a better understanding to brands, such as Realme, on the influence of brand image to customer perceived value and customer trust and the influence of customer perceived value and customer trust to purchase intention. Since Realme's targeted market is for youth or low-income people, Realme can choose to focus its sales on regions with low gross regional domestic products such as Central Java, Nusa Tenggara, West Sulawesi, etc. Moluccas (BPS-Statistics Indonesia, 2021). 
Other than that, Realme should focus on developing products with attractive specifications at a reasonable price to disrupt the low-end smartphone market. The disruption will enhance Realme brand image, and by offering a product with great value, the customer perceived value will also gain boosted. These will lead to more benefits for the company. Realme should also be honest with its advertisement to prevent reducing customer trust and influence customer's intention to purchase.

\section{Conclusion}

In the present, the smartphone's price is getting cheaper, which benefits customers by allowing them to buy a smartphone that suits their needs and budget allocations. In purchasing a smartphone, customers generally look for smartphone features and a brand image that helps influence the customer's decisions. This study demonstrates that customer trust and customer perceived value may influence purchase intention. The brand image influences customer trust and customer perceived value in Realme smartphones from the perspective of high-cost smartphone brand users, which are Apple and Samsung users. A smartphone company with a brand image that different from other brands by becoming one of the best or play an influential role in the industry will make the customer trust the company and it will make the smartphones they offered to be worth the price. Smartphone companies that are honest and open about the smartphone's information and setting the smartphones at an ideal price will increase customers' willingness to purchase the smartphones and trust the brand. Therefore, this finding is expected to help the smartphone industry to start paying attention and build a good brand image to increase sales in the future, considering that more new competitors are no less good than existing smartphone brands.

\section{Limitation and Future Research}

In this research, only samples from Indonesia were used. Most of the respondents are still categorized as young adults and live on the island of Java, specifically DKI Jakarta, where people in Jakarta tend to spend more money to follow the trend to keep up with the prestige. The living cost in Jakarta is higher due to Jakarta being the capital city of the nation, therefore gathering data from people outside of Indonesia or the island of Java as the majority and people who age are above 25 might have different results. Another limitation is that there is no clear definition regarding the low-cost and high-cost term. Considering other factors that influence the purchase intention variable, future research might use other variables such as brand awareness (Graciola et al., 2020) and EWOM (Kudeshia \& Kumar, 2017). We also recommend gathering the respondents from the Realme targeted segment, such as middle to low-income people, and research other low-cost smartphone brands.

\section{References}

Ajzen, I. (1991). The theory of planned behavior. Organizational Behavior and Human Decision Processes, 50(11), pp. 1369-1376. https://doi.org/ 10.1080/10410236.2018.1493416

Ali, A., Xiaoling, G., Sherwani, M., \& Ali, A. (2018). Antecedents of consumers' halal brand purchase intention: an integrated approach. Management Decision, 56(4), pp. 715-735. https://doi.org/10.1108/MD-11-20160785

Alrwashdeh, M., Emeagwali, O. L., \& Aljuhmani, H. Y. (2019). The effect of electronic word of mouth communication on purchase intention and brand image: An applicant smartphone brands in north Cyprus. Management Science Letters, 9(4), pp. 505-518. https://doi.org/10.5267/j.msl .2019 .1 .011 
Brand - Realme (Global). (2020). Retrieved from https://www.realme.com/global /brand

Buil, I., Martínez, E., \& de Chernatony, L. (2013). The influence of brand equity on consumer responses. Journal of Consumer Marketing, 30(1), pp. 6274. https://doi.org/10.1108/0736376 1311290849

Chen, Y. S., \& Chang, C. H. (2012). Enhance green purchase intentions: The roles of green perceived value, green perceived risk, and green trust. Management Decision, 50(3), pp. 502-520. https://doi.org/10.1108/0025 1741211216250

Chen, Y. S., Huang, A. F., Wang, T. Y., \& Chen, Y. R. (2020). Greenwash and green purchase behaviour: the mediation of green brand image and green brand loyalty. Total Quality Management and Business Excellence, 31(1-2), pp. 194-209. https://doi .org/10.1080/14783363.2018.1426450

Cheshin, A., Amit, A., \& van Kleef, G. A. (2018). The interpersonal effects of emotion intensity in customer service: Perceived appropriateness and authenticity of attendants' emotional displays shape customer trust and satisfaction. Organizational Behavior and Human Decision Processes, 144, pp. 97-111. . https://doi.org/10.1016 /j.obhdp.2017.10.002

Dhanabalan, T., Subha, K., Shanthi, R., \& Sathish, A. (2018). Factors influencing consumers' car purchasing decision in indian automobile industry. International Journal of Mechanical Engineering and Technology, 9(10), pp. 53-63.
Fornell, C., \& Larcker, D. (1981). Evaluating Structural equation models with unobservable variables and measurement error. Journal of Marketing Research, 18(1), pp. 39-50. https://doi.org/10.2307/3151312.

Gardner, B., \& Levy, S. (1999). The product and the brand. In S. J. Levy, \& D. W. Rook Brands, consumers, symbols, \& research (pp. 131-140). SAGE Publications, Inc., https://www.doi.org/10.4135/9781452 231372.n13

Graciola, A. P., De Toni, D., Milan, G. S., \& Eberle, L. (2020). Mediatedmoderated effects: High and low store image, brand awareness, perceived value from mini and supermarkets retail stores. Journal of Retailing and Consumer Services, 55(July), pp. 102$117 . \quad$ https://doi.org/10.1016/j. jretconser.2020.102117

Hair, J. F., Black, W. C., Babin, B. J., \& Anderson, R. E. (2018). Multivariate data analysis. Boston: Cengage.

Indonesia: market share of leading mobile brands. (2020). Statista. Retrieved from https://www.statista.com /statistics/937100/indonesia-marketshare-of-leading-mobile-brands/

Indonesia smartphone users. (2021). Statista. Retrieved from https:// www.statista.com/statistics/266729/s martphone-users-in-indonesia/

Jeng, S. P., \& Lo, M. F. (2019). Lowest price guarantees on airline websites: Perceived believability, perceived value, and purchase intentions. Journal of Air Transport Management, 75(December), pp. 85-91. https://doi.org/10.1016/j.jairtraman.20 18.12.002 
Kim, H., \& Lee, C. W. (2018). The Effects of customer perception and participation in sustainable supply chain management: A Smartphone Industry Study. Sustainability, 10(7), pp. 1-19. https://doi.org/10.3390 /su100 72271

Konuk, F. A. (2018). The role of store image, perceived quality, trust and perceived value in predicting consumers' purchase intentions towards organic private label food. Journal of Retailing and Consumer Services, 43(March), pp. 304-310. https://doi.org/10.1016/j.jretconser.20 18.04.011

Konuk, F. A. (2019). The influence of perceived food quality, price fairness, perceived value and satisfaction on customers' revisit and word-of-mouth intentions towards organic food restaurants. Journal of Retailing and Consumer Services, 50(May), pp. 103-110. https://doi.org/10.1016/j .jretconser.2019.05.005

Kudeshia, C., \& Kumar, A. (2017). Social eWOM: does it affect the brand attitude and purchase intention of brands? Management Research Review, 40(3), pp. 310-330. https://doi.org/10.1108/MRR-072015-0161

Lee, J., \& Lee, Y. (2018). Effects of multibrand company's CSR activities on purchase intention through a mediating role of corporate image and brand image. Journal of Fashion Marketing and Management, 22(3), pp. 387-403. https://doi.org/10. 1108/JFMM-08-2017-0087
Lien, C. H., Wen, M. J., Huang, L. C., \& $\mathrm{Wu}, \mathrm{K}$. L. (2015). Online hotel booking: The effects of brand image, price, trust and value on purchase intentions. Asia Pacific Management Review, 20(4), pp. 210-218. https://doi.org/10.1016/j.apmrv.2015. 03.005

Lin, Y. H., Lin, F. J., \& Wang, K. H. (2020). The effect of social mission on service quality and brand image. Journal of Business Research, (June). https://doi.org/10.1016/j.jbusres.2020. 10.054

Logaritma, S. (2021). Gross Regional Domestic Product of provinces in Indonesia by Industry 2016 - 2020. Jakarta : BPS-Statistics Indonesia.

Loureiro, S. M. C., Kassar, A.-N., \& Itani, O. S. (2019). Value get, value give: The relationships among perceived value, relationship quality, customer engagement, and value consciousness. International Journal of Hospitality Management. $\quad$ https://doi.org/10 $.1016 /$ j.ijhm.2019.01.014

Macmud, A., \& Hidayat, Y. M. (2020). The factors affecting smartphone demand in Indonesia. International Journal of Innovation, Creativity and Change, 13(3), pp. 406-418.

Martins, J., Costa, C., Oliveira, T., Gonçalves, R., \& Branco, F. (2019). How smartphone advertising influences consumers' purchase intention. Journal of Business Research, 94(August), pp. 378-387. https://doi.org/10.1016/j.jbusres .2017 .12 .047 
Mohseni, S., Jayashree, S., Rezaei, S., Kasim, A., \& Okumus, F. (2018). Attracting tourists to travel companies' websites: the structural relationship between website brand, personal value, shopping experience, perceived risk and purchase intention. Current Issues in Tourism, 21(6), pp. 616-645. https://doi.org/10.1080 /13683500.2016.1200539

Nunnally, J. C. (1994). Psychometric theory $3^{\text {rd }}$ ed. New York : Tata McGraw-hill education.

Paparoidamis, N. G., Katsikeas, C. S., \& Chumpitaz, R. (2019). The role of supplier performance in building customer trust and loyalty: A crosscountry examination Industrial Marketing Management 78(April). pp. 183-197 https://doi.org/10.1016 /j.indmarman.2017.02.005

Peng, L., Zhang, W., Wang, X., \& Liang, S. (2019). Moderating effects of time pressure on the relationship between perceived value and purchase intention in social E-commerce sales promotion: Considering the impact of product involvement. Information and Management, 56(2), pp. 317-328. https://doi.org/10.1016/j.im.2018.11.0 07

Rita, P., Oliveira, T., \& Farisa, A. (2019). The impact of e-service quality and customer satisfaction on customer behavior in online shopping. Heliyon, 5(10), e02690. https://doi.org/10 .1016/j.heliyon.2019.e02690

Rotter, J. B. (1967). A new scale for the measurement of interpersonal trust. Journal of Personality, 35(4), pp. 651665.
Ryu, K., Han, H., \& Kim, T. H. (2008). The relationships among overall quickcasual restaurant image, perceived value, customer satisfaction, and behavioral intentions. International Journal of Hospitality Management, 27(3), pp. 459-469. https://doi. org/10.1016/j.ijhm.2007.11.001

Ryu, K., Lee, H.-R., \& Kim, W. G. (2012). The influence of the quality of the physical environment, food, and service on restaurant image, customer perceived value, customer satisfaction, and behavioral intentions Kisang. International Journal of Contemporary Hospitality Management, 24(2), pp. 200-223. https://doi.org/10.1108 /09596111211206141

Sasmita, J., \& Mohd Suki, N. (2015). Young consumers' insights on brand equity. International Journal of Retail \& Distribution Management, 43(3), pp. 276-292. https://doi.org/10. 1108/IJRDM-02-2014-0024

Sekaran, U., \& Bougie, R. (2014). Research methods for business. Chichester: John Wiley.

Smartphone market share. (2021). Statista. Retrieved from https://www.statista. com/statistics/271496/global-marketshare-held-by-smartphone-vendorssince-4th-quarter-2009/

Smartphone users. (2021). Statista. Retrieved from https://www.statista .com/statistics/330695/number-ofsmartphone-users-worldwide/

Smartphone users by country. (2021). Statista. Retrieved from https:// www.statista.com/statistics/748053/w orldwide-top-countries-smartphoneusers/ 
Talwar, S., Jabeen, F., Tandon, A., Sakashita, M., \& Dhir, A. (2021). What drives willingness to purchase and stated buying behavior toward organic food? A Stimulus-OrganismBehavior-Consequence (SOBC) perspective. Journal of Cleaner Production, 293(2021, April 15), https://doi.org/10.1016/j.jclepro.2021. 125882

The rise of the cheap smartphone. (2014). The Economist, (April 5). Retrieved from https://www.economist.com /business/2014/04/05/the-rise-of-thecheap-smartphone

Weisstein, F. L., Song, L., Andersen, P., \& Zhu, Y. (2017). Examining impacts of negative reviews and purchase goals on consumer purchase decision. Journal of Retailing and Consumer Services, 39(July), pp. 201-207. https://doi.org/10.1016/j.jretconser.20 17.08.015

Wong, K. K. K. (2013). Partial least squares structural equation modeling (PLSSEM) techniques using SmartPLS. Marketing Bulletin, 24(1), pp. 1-32.

Woo, E., \& Kim, Y. G. (2019). Consumer attitudes and buying behavior for green food products: From the aspect of green perceived value (GPV). British Food Journal, 121(2), pp. 320332. https://doi.org/10.1108/BFJ-012018-0027

Xu, J. (David), Cenfetelli, R. T., \& Aquino, K. (2016). Do different kinds of trust matter? An examination of the three trusting beliefs on satisfaction and purchase behavior in the buyer-seller context. Journal of Strategic Information Systems, 25(1), pp. 15-31. https://doi.org/10.1016/j.jsis.2015.10. 004
Ye, S., Ying, T., Zhou, L., \& Wang, T. (2019). Enhancing customer trust in peer-to-peer accommodation: A "soft" strategy via social presence. International Journal of Hospitality Management, 79(October), pp. 1-10. https://doi.org/10.1016/j.ijhm.2018.11 .017

Yeh, Y. S., \& Li, Y. M. (2009). Building trust in m-commerce: Contributions from quality and satisfaction. Online Information Review, 33(6), pp. 10661086. https://doi.org/10.1108/1468452 0911011016

Zeithaml, V. A. (1988). Consumer perceptions of price, quality, and value: a means-end model and synthesis of evidence. Journal of Marketing, 52(3), pp. 2-22. https://doi.org/10.1177/00222429880 5200302 